\title{
IMPROVEMENT PERFORMANCE OF AL-WATHBA SETTLING TANK BY A COMPUTATIONAL FLUID DYNAMICS MODEL
}

\author{
JOZEF KRIŚ ${ }^{1)}$, GHAWI A. HADI ${ }^{2)}$ \\ ${ }^{1)}$ Slovak University of Technology, Faculty of Civil Engineering, Department of Sanitary and Environmental Engineering, \\ Radlinského 11,81368 Bratislava, Slovakia; Mailto: kris@svf.stuba.sk, \\ ${ }^{2)}$ Al-Qadissiyia University, College of Engineering Department of Civil Engineering, Iraq; Mailto: ghawi2000@yahoo.com
}

An investigation has been carried out using the FLUENT Computational Fluid Dynamics (CFD) software, which uses the finite-volume method to determine whether it is feasible to improve the capacity and quality of the clarifier at the Al-Wathba Water Treatment Works (Iraq) by some relatively inexpensive means. Simulations were carried out with two dimensional, radially symmetric models, representing the existing configuration as well as a number of proposed modifications involving baffles and additional clarified water off-takes. A convection-diffusion equation, which is extended to incorporate the sedimentation of sludge flocs in the field of gravity, governs the mass transfer in the clarifier. The standard $k-\varepsilon$ turbulence model is used to compute the turbulent motion, and our CFD model accounts for buoyancy flow. The sludge settling velocity was measured as a function of the concentration, and we have used the double-exponential settling velocity function to describe its dependence on the concentration. The CFD model is validated using measured concentration profiles. The results were evaluated on the basis of the simulated profiles of vertical up-flow velocity in the body of the clarifier.

KEY WORDS: Computational Fluid Dynamics, Water Treatment, Clarifiers, Baffle, Water Quality.

Jozef Kriš, Ghawi A. Hadi: ZLEPŠENIE ČINNOSTI SEDIMENTAČNEJ NÁDRŽE AL-WATHBA POMOCOU CFD MODELU - POČÍTAČOVEJ SIMULÁCIE PRÚDENIA KVAPALÍN. J. Hydrol. Hydromech., 58, 2010, 3; 15 lit., 7 obr., 4 tab.

Pri výskume bol použitý softvér FLUENT CFD, ktorý využíva metódu konečných objemov na určovanie toho, či možno zlepšit' kapacitu a kvalitu číričov v úpravni vody Al-Wathba (Irak) niektorým z relatívne nenákladných spôsobov. Simulácie sa uskutočnili s využitím 2D radiálne symetrických modelov, ktoré predstavovali skutočnú konfiguráciu ako aj počet navrhnutých modifikácií s usmerňovačmi a dodatočnými odtokmi upravenej vody. Konvekčno-difúzna rovnica, ktorá je rozšŕrená o sedimentáciu kalových vločiek v gravitačnom poli, určuje prenos hmoty v číriči. Na výpočet turbulentného pohybu sme použili štandardný model turbulencie $k-\varepsilon$ a na vztlakové prúdenie CFD model. Rýchlost' usadzovania kalu bola meraná ako funkcia koncentrácie, pričom my sme použili dvojexponenciálnu funkciu rýchlosti usadzovania na opis závislosti od koncentrácie. CFD model je overený pomocou meraných profilov koncentrácií. Výsledky boli vyhodnotené na základe simulovaných profilov vertikálnej rýchlosti prúdenia v číriči smerom nahor.

KLUUČOVÉ SLOVÁ: počítačová simulácia prúdenia kvapalín, úprava vody, číriče, usmerňovače, kvalita vody.

\section{Introduction}

For nearly two years, the Al-Wathba Water Treatment Plant has been undergoing a \$22 million upgrade to bring more fresh potable water to Baghdad residents. That facility serves the Rusafa area in northeast Baghdad with markets, businesses, medical facilities, and about 300,000 residents dependent on its output. "Al-Wathba is over 40 years old and the dilapidated, poorly maintained equipment was producing about 1,000 cubic meters of drinking water per hour. We expanded the plant's capacity almost $2 \frac{1}{2}$ times and it is now able to produce 2,400 cubic meters of water per hour.

The Al-Wathba water treatment plant is an existing water treatment plant in Baghdad, Iraq. The plants purpose is to pump water from the Tigris River, treat the water to potable standards, and then pump pressurized water to the local distribution system where it is utilized by residences and busi- 
nesses. The facility was initially constructed in 1934 and expanded in 1964 and 1976. Due to substantial deterioration, the plant requires expensive rehabilitation.

Current operations at the facility include pumping water from the Tigris River and treating the water through three parallel treatment trains. Treatment train 1, which was constructed in 1934, consists of clarifier, an alum feed to the clarifier tank, a settling tank, pressure filtration, chlorination, and high lift pumps to the distribution system. Treatment train 2, which was constructed in 1964, consists of alum feed to clarifier flash mix tanks, a clarifier, a settling tank, rapid sand gravity filtration, chlorination, and high lift pumps to the distribution system. Train 3, which was constructed in 1976 , is a gravity filtration system similar to treatment train 2.

The Al-Wathba waterworks has circular clarifier in train 1 (Fig. 1). The water requirement of the area is very seasonal, with a strong increase in demand over the May-October summer period, during which the clarifiers appear to have insufficient capacity and not good quality. It is anticipated that the works will only be in operation for a few more years, so that a large investment in additional capacity is difficult to justify. It would therefore be most desirable if an inexpensive means could be found to increase the capacity of the existing units. It had been noticed that the clarified water off-take weir was significantly out of level, leading to a circumferential mal-distribution of flow. Installation of a multiple V-notch weir was planned, which should remedy this situation. A uniform circumferential distribution of flow was assumed as a starting point for this investigation.

Tab. 1 shows the settling tank design characteristics. The settling tank is circular with a peripheral inlet system and peripheral overflow weir with vnotch profile. The bottom floors have a steep slope of $20^{\circ}$ and a blade scraper moves the sludge towards a central conical sludge hopper. No scum removal facilities are installed.

A number of studies have investigated sediment distribution and flow patterns in sedimentation tanks and clarifiers (Simanjuntak, Boeriu, Roelvink, 2009). Several of the studies (Krebs et al. 1996, Brouckaert and Buckley, 1999. Lakehal et al. 1999, Jayanti and Narayanan, 2004, Ghawi and Kris, 2007, have been carried by use of CFD model.

The overall objective of this task orders it to increase the quantity and quality of potable water available to citizens living in Baghdad by rehabili- tation of the existing water thereby improving their living conditions by use CFD model.

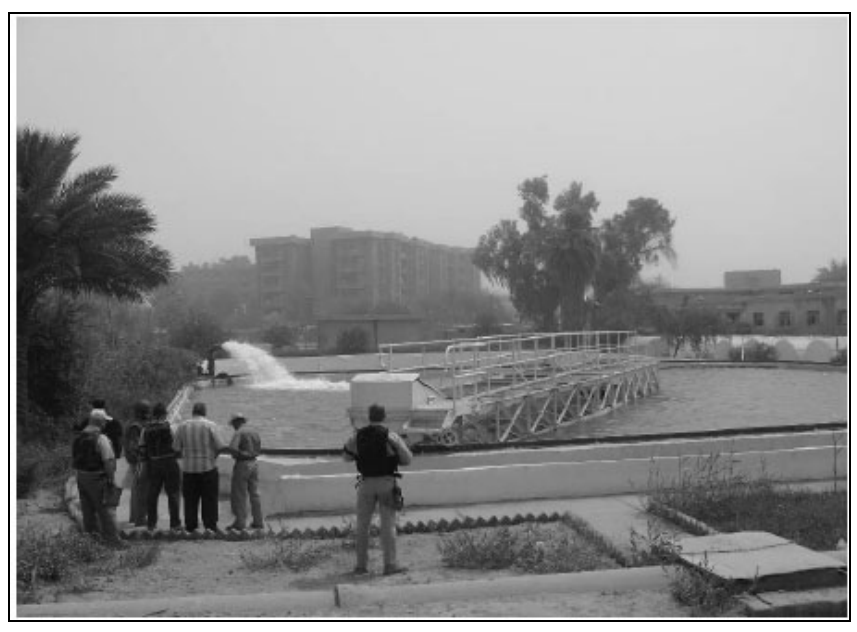

Fig. 1. Train 1 clarifier tank.

Obr. 1. Č́rič.

$\mathrm{T}$ a b $1 \mathrm{e}$ 1. Settling tank characterizations.

T a b u l'k a 1. Opis usadzovacej nádrže.

\begin{tabular}{lc}
\hline Parameter & Value \\
\hline Radius $[\mathrm{m}]$ & 7.750 \\
Area $\left[\mathrm{m}^{2}\right]$ & 169.8 \\
Average depth $[\mathrm{m}]$ & 4.2 \\
Side wall depth $[\mathrm{m}]$ & 2.980 \\
$Q_{\text {inlet }}\left[\mathrm{m}^{3} \mathrm{~d}^{-1}\right]$ & 5712 \\
\hline
\end{tabular}

\section{Computational fluid dynamics model}

Computational fluid dynamics is essential to model solid particulate transport in the clarifier. To calculate the flow field, the equations for mass (continuity), the axial and radial momentum conservation and the bulk density have to be solved (Ekama et al., 1997):

$$
\frac{\partial}{\partial t} \rho+\frac{\partial}{\partial x} \rho u+\frac{\partial}{\partial r} \rho v+\frac{\rho v}{r}=0,
$$

$\frac{\partial}{\partial t} \rho u+\frac{1}{r} \frac{\partial}{\partial x} r \rho u u+\frac{1}{r} \frac{\partial}{\partial r} r \rho v u=-\frac{\partial p}{\partial x}+$

$+\frac{1}{r} \frac{\partial}{\partial x}\left[r \rho v_{e f f}\left(2 \frac{\partial u}{\partial x}-\frac{2}{3}\left(\frac{\partial u}{\partial x}+\frac{\partial v}{\partial r}+\frac{v}{r}\right)\right)\right]+$

$+\frac{1}{r} \frac{\partial}{\partial r}\left[r \rho v_{e f f}\left(\frac{\partial u}{\partial r}+\frac{\partial v}{\partial x}\right)\right]-\rho \mathrm{g}$,

$$
\frac{\partial}{\partial t} \rho v+\frac{1}{r} \frac{\partial}{\partial x} r \rho u v+\frac{1}{r} \frac{\partial}{\partial r} r p v v=-\frac{\partial p}{\partial r}+
$$




$$
\begin{aligned}
& +\frac{1}{r} \frac{\partial}{\partial x}\left[r \rho v_{e f f}\left(\frac{\partial v}{\partial x}+\frac{\partial u}{\partial r}\right)\right]+ \\
& +\frac{1}{r} \frac{\partial}{\partial x}\left[r \rho v_{e f f}\left(2 \frac{\partial u}{\partial r}-\frac{2}{3}\left(\frac{\partial u}{\partial x}+\frac{\partial v}{\partial r}+\frac{v}{r}\right)\right)\right]- \\
& -2 \rho v_{e f f} \frac{v}{r^{2}}+\frac{2}{3} \frac{\rho v_{e f f}}{r}\left(\frac{\partial u}{\partial x}+\frac{\partial v}{\partial r}+\frac{v}{r}\right) \\
& \rho=\frac{\rho_{1}}{1-\Phi\left(1-\frac{\rho_{1}}{\rho_{s}}\right)}
\end{aligned}
$$

where $x$ is the axial coordinate, $r$ - the radial coordinate, $t$ - time, $\rho$ - bulk density, $u$ - the axial velocity, $\rho_{l}$ and $\rho_{s}-$ the liquid and dry solids densities (1000 and $1550 \mathrm{~kg} \mathrm{~m}^{-3}$, respectively) and $v$ - the radial velocity, $\mathrm{g}$ and $v_{\text {eff }}$ - the gravitational acceleration and the effective viscosity; the latter includes both the molecular $v$ and turbulent viscosity $v_{t}$, i.e.

$$
\begin{aligned}
& v_{\text {eff }}=v+v_{t}, \\
& v_{t}=C_{\mu} \frac{k^{2}}{\varepsilon} .
\end{aligned}
$$

The turbulent kinetic energy $k$ and the energy dissipation $\varepsilon$ are essential to calculate this turbulent viscosity ( $c_{\mu}$ is an empirical constant). They can be modelled in several ways (Rodi, 1984). Here, transport equations for these variables are set up and have to be solved together with the continuity and momentum equations. $\sigma_{k}, \sigma_{\varepsilon}, c_{1}$ and $c_{2}$ are constants.

$$
\begin{aligned}
& \frac{\partial}{\partial t} \rho k+\frac{1}{r} \frac{\partial}{\partial x} r \rho k u+\frac{1}{r} \frac{\partial}{\partial r} r \rho k v= \\
& =\frac{1}{r} \frac{\partial}{\partial r}\left[r \rho\left(v+\frac{v_{t}}{\sigma_{k}}\right) \frac{\partial k}{\partial r}\right]+ \\
& +\frac{1}{r} \frac{\partial}{\partial x}\left[r \rho\left(v+\frac{v_{t}}{\sigma_{k}}\right) \frac{\partial k}{\partial x}\right]+P_{s}-p \varepsilon \\
& \frac{\partial}{\partial t} \rho \varepsilon+\frac{1}{r} \frac{\partial}{\partial x} r \rho \varepsilon u+\frac{1}{r} \frac{\partial}{\partial r} r \rho \varepsilon v= \\
& =\frac{1}{r} \frac{\partial}{\partial r}\left[r \rho\left(v+\frac{v_{t}}{\sigma_{\varepsilon}}\right) \frac{\partial \varepsilon}{\partial r}\right]+ \\
& +\frac{1}{r} \frac{\partial}{\partial x}\left[r \rho\left(v+\frac{v_{t}}{\sigma_{\varepsilon}}\right) \frac{\partial \varepsilon}{\partial x}\right]+c_{1 \varepsilon} \frac{\varepsilon}{k} P_{s}-c_{2 \varepsilon} \rho \frac{\varepsilon^{2}}{k}
\end{aligned}
$$

where

$$
P_{s}=\mu_{e f f}\left[2\left(\frac{\partial u}{\partial r}\right)^{2}+2\left(\frac{\partial v}{\partial x}\right)^{2}+2\left(\frac{u}{r}\right)^{2}+\left(\frac{\partial u}{\partial x}+\frac{\partial v}{\partial r}\right)^{2}\right]
$$

in which $c_{1 \varepsilon}=1.44, c_{2 \varepsilon}=1.92, \sigma_{\varepsilon}=1.3$, and $\sigma_{k}=1.0$ are given by e.g. Rodi (1984).

In the equations above, only one phase has been considered. The proposed approach here is that water and sludge are modelled as a mixture with the same velocity for all mixture components. To take into account specific transport processes for the sludge, e.g. settling, one can set up so-called scalar transport equations.

$$
\begin{aligned}
& \frac{\partial}{\partial t} \rho \Phi+\frac{1}{r} \frac{\partial}{\partial x} r \rho \Phi\left(u-v_{s}\right)+\frac{1}{r} \frac{\partial}{\partial r} r \rho \Phi v= \\
& =\frac{1}{r} \frac{\partial}{\partial x}\left(r \frac{v_{e f f}}{\sigma_{s}} \frac{\partial}{\partial x} \rho \Phi\right)+\frac{1}{r} \frac{\partial}{\partial r}\left(r \frac{v_{e f f}}{\sigma_{s}} \frac{\partial}{\partial r} \rho \Phi\right),
\end{aligned}
$$

where $v_{s}$ is the settling velocity (Eq. (7)), $\Phi-$ the solids mass fraction and $\sigma_{s}-$ the Schmidt number. Traditionally, the last-mentioned is taken as 0.7 (e.g. Adams \& Rodi, 1990; Szalai et al., 1994; Krebs et al., 1996; Lakehal et al., 1999).

The settling velocity of the suspended solids is not constant, but depends on the water temperature, floc size, the floc density and the floc concentration. The settling velocity was specified as a function of concentration (Takács, Patry and Nolasco (1991) and Patry and Takács (1992)). This formulation allows higher settling velocities for higher concentrations and lower settling velocities for lower concentrations.

$$
v_{s}=v_{0}\left[e^{-r_{h}\left(x-x_{0}\right)}-e^{-r_{p}\left(x-x_{0}\right)}\right] \text {, }
$$

where $v_{0}$ is the maximum settling velocity, $r_{h}-$ the parameter characteristic for the hindered settling zone, $r_{p}-$ a characteristic settling parameter at low solids concentrations, and $X_{0}$ is the concentration below which no settling occurs. Eq. (7) parameters are summarized in Tab. 2.

\section{Boundary conditions}

The above equations form a set of partial differential equations. In order to obtain a unique solution, this set needs to be linked to a set of boundary conditions. The boundary conditions include: 1 . The inlet was specified as a uniform velocity, solids 
T a b l e 2. Settling parameters used in this paper.

$\mathrm{T} a \mathrm{bu} \mathrm{l}$ ' $\mathrm{k}$ a 2 . Parametre usadzovania použité v tejto práci.

\begin{tabular}{cc}
\hline Parameter & Value \\
\hline$v_{0}\left[\mathrm{~m} \mathrm{~s}^{-1}\right]$ & 0.0043 \\
$r_{h}\left[1 \mathrm{~g}^{-1}\right]$ & 0.26 \\
$r_{p}\left[1 \mathrm{~g}^{-1}\right]$ & 3.89 \\
$X_{0}\left[\mathrm{~g} \mathrm{l}^{-1}\right]$ & 0.05 \\
$v_{i}\left[\mathrm{~m} \mathrm{~s}^{-1}\right]$ & 0.03 \\
$\boldsymbol{c}_{\boldsymbol{\mu}}$ & 0.09 \\
\hline
\end{tabular}

concentration $k$ and $\varepsilon$ values; 2 . The overflow outlets were specified in the top row of cells on either side of the overflow weirs. A zero gradient boundary condition was imposed for all variables. In order to conserve mass, the outflow of mass was balanced with the inflow. To ensure a uniform distribution across the overflow weirs, a number of boundaries was specified, each with a fixed mass flux ratio. The total overflow mass flux ratio was set to $96 \%$; 3 . The underflow outlet was specified in the bottom of the hopper(s). The total mass flow ratio of the underflow was set at $4 \%$. This accounted for the removal of sludge from the hopper; 4. The vertical and horizontal walls were specified as near wall boundaries using the standard $k-\varepsilon$ model (Rodi, 1993); 5. The static free surface was specified as a rigid lid symmetry axis. The variables that were not specified according to a rigid lid symmetry axis were the concentration (for which a zero flux boundary was applied) and the kinetic energy dissipation (where the values as used by Zhou and McCorquodale (1992) were specified); 6 . The interaction of the solids with the bottom wall was modelled by an implicit bottom boundary condition (Zhou and McCorquodale, 1992). This was used to calculate the solids concentration at the bottom as a function of the solids concentration near the bottom, the settling velocity and scouring parameter.

\section{Solution of the governing equations}

In a CFD solution, the flow domain is broken up into a number of contiguous and nonoverlapping cells enveloping the whole domain and the flow variables are sought at the centers of each of these cells. The governing equations are therefore discretized and linearized in the present case, by a finite volume scheme. Resulting in a set of coupled, linear algebraic equations which are then solved using iterative schemes. The various steps in this scheme of solution have become sufficiently standardized that commercially available CFD codes can be used to solve the governing equations. This approach is resorted to in the present case and all the calculations reported here have been done using the CFD code FLUENT developed by Fluent Inc. The version used in the present calculations is a finitevolume based code using unstructured meshes to discretize the flow domain. The value of the numerical schemes were used in the numerical model are listed in Tab. 3 (Fluent, 2006)

$\mathrm{T}$ a b 1 e 3. Summary of the numerical schemes applied (Fluent, 2006).

T a b u l'k a 3. Súhrn použitých numerických schém (Fluent, 2006).

\begin{tabular}{ll}
\hline \multicolumn{2}{c}{ Numerical scheme } \\
\hline Pressure interpolation & body-force-weighted \\
Pressure-velocity coupling & PISO \\
Advection term & QUICK \\
Diffusion term & central difference \\
Time & second-order upwind \\
$k$ & QUICK \\
$\varepsilon$ & QUICK \\
Solids fraction & QUICK \\
\hline
\end{tabular}

\section{Material and method}

Before the study reached the implementation and evaluation stages, Al-Wathba Water were able to reduce the demand for water at the treatment works by eliminating some major leaks in the system, and the need to upgrade the clarifier fell away. Although this was disappointing from the point of view of the CFD project, it did provide an object lesson on the need to apply demand management before considering any technological measures to increase production capacity.

In this case study, a series of CFD models were generated to support the design work for modifications to a clarifier which needed to have its performance upgraded. The peripheral feed arrangement for this clarifier was particularly unusual, and caused it to be plagued by poor feed distribution resulting in severe short-circuiting.

In June 2005, Al-Wathba Water reviewed the existing design and made recommendations on proposed improvements to Clarifier. The working group tabled the following design proposal:

Convert the existing peripheral inlet system to a central inlet, which required construction of the inlet pipe below the existing floor (Fig. 2). Fig. 2 is a half-sectional diagram representing the features of the clarifier, which are of interest to the CFD model. 
Sludge samples were collected with a peristaltic pump (Chemaster dose pump CP-Z/100-P-DC) and $6 \mathrm{~mm}$ ID PVC tubing. The tubing was mounted on a rigid PVC pole. Samples of $70 \mathrm{ml}$ were taken below the solids blanket and at the settling tank's inlet. Instead, $200 \mathrm{ml}$-volume samples were collected above the blanket. The latter allowed a more accurate determination of solids weight. The solids concentration was determined according to Standard Methods (APHA, 1992). To quantify the measurement accuracy ten repetitions of three different concentrations have been examined on their $95 \%$ confidence interval. The samples covered the range of concentrations dealt with in practice.

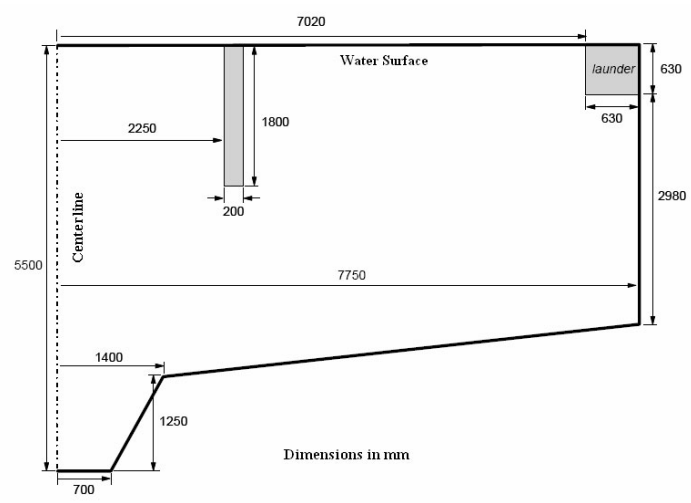

Fig. 2. Half-section diagram of Al-Wathba Water Treatment Plant.

Obr. 2. Polovica prierezu charakterizujúca čírič úpravne vody Al-Wathba.

Steady-state solids concentration profiles were investigated on 19 July 2006 . To study the dynamics, samples were taken hourly between 4 am and $3 \mathrm{pm}$ at the following settling tank locations, - inlet, - effluent.

Steady-state solids concentration profiling was conducted between 2:30 pm and 4:30 am when the most stable inlet flow rates occurred. Confrontation of measured profiles and data from the mounted acoustic solids blanket depth sensor (located at approximately $8 \mathrm{~m}$ from the tank's centre) revealed that the latter blanket depth corresponded to solids concentrations of between $25-65 \mathrm{mg} \mathrm{l}^{-1}$.

\section{Model validation}

The simulated solids concentrations should be validated with measured profiles. The validation consisted of comparing simulations with steadystate solids concentration profiles measured at 4 different radial distances, i.e. 2, 4, 6, and $7 \mathrm{~m}$, all situated outside the feed well. The profiling was conducted at afternoon flow rates. Simulated profiles were recorded every 20 minutes giving a range of profiles between which the measured solids concentrations should be found for successful validation. Results are shown in Fig. 3.

Without any additional calibration, an excellent agreement is found between simulations and measurements. Only close to the bottom floor at a radial distance of $2 \mathrm{~m}$, the simulated concentration largely deviates from the measured value. A possible cause may be a clump of solids stuck to the bottom, not being removed by the scraper. Badly modelled solids compression also leads to lower bottom floor concentrations.
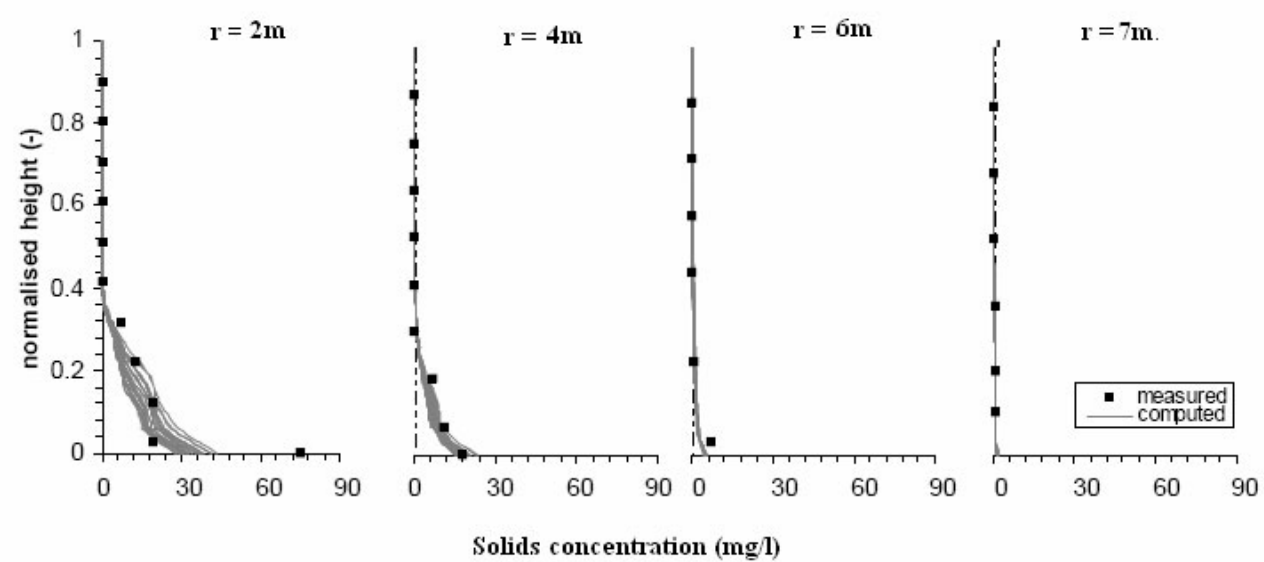

Fig. 3. Comparison between simulated and measured solids concentration profiles. Simulated profiles were recorded every 20 minutes.

Obr. 3. Porovnanie simulovaných a nameraných profilov koncentrácií pevných častíc. Simulované profily boli zaznamenávané každých 20 minút. 


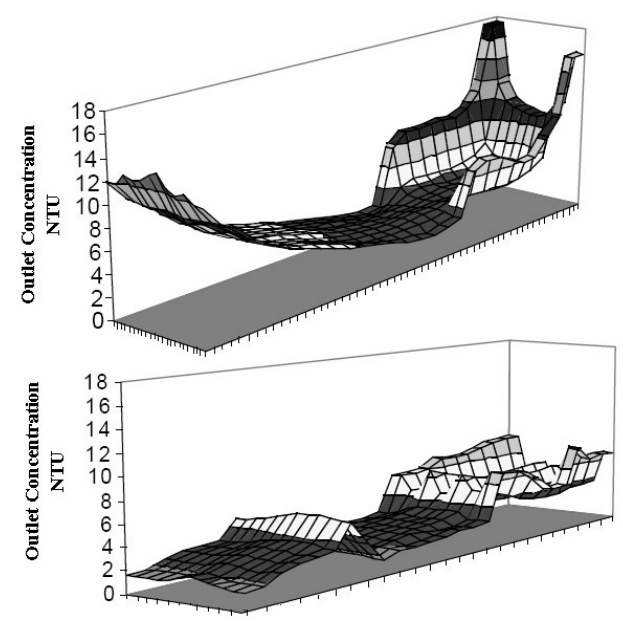

Fig. 4. Outlet concentration before and after retrofit. Obr. 4. Koncentrácie na odtoku pred úpravou systému a po nej.

\section{Result and discussion}

\subsection{Existing clarifier performance}

As shown in Fig. 4 (top), the existing clarifiers at Al-Wathba Treatment Plant, often experience high effluent solid concentration. In the overloaded clarifier, the effluent solid concentration is extremely sensitive to any minor variations in plant flow.

The flow capacity for the Al-Wathba existing clarifier studied ranges from 200 to $450 \mathrm{~m}^{3} \mathrm{~h}^{-1}$ due to variations of the process parameters. The clarifier is unable to achieve their expected design flow of $405 \mathrm{~m}^{3} \mathrm{~h}^{-1}$ due primarily to the thickening limitation of clarifiers.

Fig. 5 shows a cross-sectional diagram of the modified clarifier, with the simulated flow field for an overflow rate of $242 \mathrm{~m}^{3} \mathrm{~h}^{-1}$, which corresponds to an average up-flow velocity of $0.045 \mathrm{~cm} \mathrm{~s}^{-1}$ over the annular area between the baffle and the outer wall. The arrows give an impression of the flow pattern in the settling section; their lengths are proportional to the velocities. The contour lines show the distribution of the vertical component of velocity.

The critical horizontal plane is taken to be from the bottom of the baffle to the outer wall (shown as $\mathrm{AB}$ in Fig. 5), and it can be seen that the maximum upward velocity across this section is just less that $0.12 \mathrm{~cm} \mathrm{~s}^{-1}$, about 3 times the nominal design value. It can also be seen that part of the reason for this is that a substantial portion of the area towards the centre is occupied by down-flowing water, thus reducing the effective area of the clarification section.

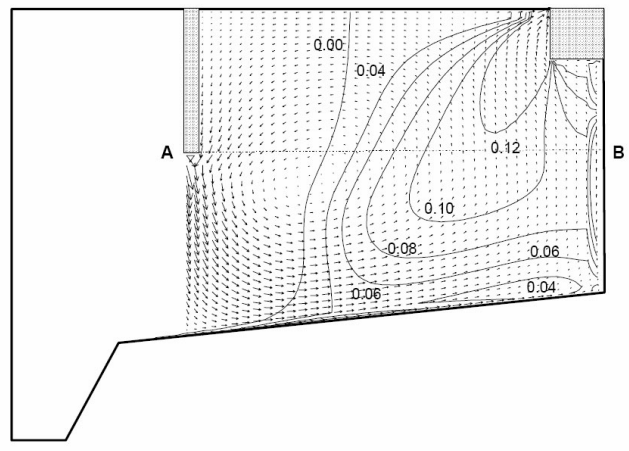

Fig. 5. Simulation of existing clarifier (contours of vertical velocity in $\mathrm{cm} \mathrm{s}^{-1}$ ).

Obr. 5. Simulácia existujúceho číriča (čiary vertikálnej rýchlosti $\mathrm{v} \mathrm{cm} \mathrm{s}^{-1}$ ).

Based on these results, it seemed that attempts to increase the capacity of the clarifier should aim to increase the area over which up-flow occurs by minimizing the area in which down-flow occurs.

\subsection{Performance of clarifiers with an optimized influent structure}

The 2D clarifier modeling technology was used to evaluate the retrofit alternative. Improved clarifier hydraulic behavior as well as enhanced performance can be observed in the following aspects:

1. Fig. 6 shows a simulation of the clarifier fitted with a small annular baffle mounted just below the shroud. The idea behind it was to achieve a more even distribution of radial flow outwards across that cylindrical area between the bottom edge of the shroud and the clarifier floor immediately beneath it, and thereby to reduce the circulatory flow in the settling section. The inner edge of the baffle protrudes slightly into the down flow inside the shroud and diverts it into the settling section. The best result was obtained with the baffle angled slightly downwards, to prevent sludge being immediately projected into the region above the bottom edge of the shroud. Unfortunately, this complicates the construction of the baffle, as it makes its surface a conical section rather than the annular section if the angle was simply horizontal. As shown, the simulation predicts that this baffle should result in a capacity improvement of about $25 \%$.

2. Further capacity could be obtained by the use an additional clarified water withdrawal system, as indicated in Fig. 7. This would have to be an annular pipe floating just below the surface, with a series of holes to admit the clarified water. The 
whole arrangement would have to rotate with the bridge, with a take-off pipe attached to the bridge itself, and discharging over the existing weir into the clarified water collection channel. This might possible be achieved with just a syphon arrangement, but it is more likely that a pump would be necessary, which could also be mounted on the bridge. On the face of it, it seems that such an arrangement would be relatively expensive to install, and would involve extra operational difficulties, which may be difficult to justify at the Al-Wathba Water works. With all these options installed, the simulations predict that the clarifier should have $175 \%$ of its original capacity.

$\mathrm{T}$ a b $1 \mathrm{e}$ 4. Summary of 2D modeling results.

T a b u l'k a 4. Súhrn výsledkov 2 D modelovania.

\begin{tabular}{|l|c|c|c|}
\hline & $\begin{array}{c}Q=255 \\
{\left[\mathrm{~m}^{3} \mathrm{~s}^{-1}\right]}\end{array}$ & $\begin{array}{c}Q=336 \\
{\left[\mathrm{~m}^{3} \mathrm{~s}^{-1}\right]}\end{array}$ & $\begin{array}{c}Q=405 \\
{\left[\mathrm{~m}^{3} \mathrm{~s}^{-1}\right]}\end{array}$ \\
\hline & \multicolumn{3}{|c|}{ Predicted average effluent turbidity (NTU) } \\
\hline Existing tank & 12 & 16 & 17 \\
\hline $\begin{array}{l}\text { Modification } \\
1,2\end{array}$ & 5.2 & 9.2 & 10 \\
\hline $\begin{array}{l}\text { Modification } \\
1,3\end{array}$ & 5.0 & 6.3 & 6.5 \\
\hline $\begin{array}{l}\text { Modification } \\
4,5\end{array}$ & 4.5 & 5.0 & 5.2 \\
\hline
\end{tabular}

Modification $1=$ Inlet flocculation baffle, the distance from tank influent to the baffle $=2.6 \mathrm{~m}$ and the baffle depth $=2.4$ $\mathrm{m}$ (the space under the baffle lip $=41 \%$ of the flow cross section area).

Modification 2 = A conventional baffle between A and B with baffle depth of $1.73 \mathrm{~m}$ below the surface (the space under the baffle lip $=58 \%$ of the flow cross section area).

Modification $3=\mathrm{A}$ conventional baffle between A and inlet with baffle depth of $1.39 \mathrm{~m}$ below the surface (the space under the baffle lip $=66 \%$ of the flow cross section area). Modification $4=$ Circular baffle mounted just above the floor of the clarifier (the dimension of the baffle was: radius $4180 \mathrm{~mm}$, hight $-320 \mathrm{~mm}$, gap between baffle and floor $-190 \mathrm{~mm}$ ).

Modification $5=$ Two baffles mounted below the shroud.

Total of the four alternatives tested by 2D modeling are presented in Tab. 4.

The relationship between the effluent solid concentration and the hydraulic loading is summarized in Tab. 4 for the existing clarifier and ones with three different modification combinations.

The predicted solid concentration in Tab. 4 indicates that the average solid concentration can be significantly reduced by improving the tank hydraulic efficiency. The comparison of model predictions with the subsequent field data indicates that the significantly improvement of clarifier per- formance was obtained by using the minor modifications based on the 2-D computer modeling.

The existing clarifiers have flow capacities of approximately $290\left(\mathrm{~m}^{3} \mathrm{~h}^{-1}\right)$ under the normal process condition, which is most of the year. The optimized clarifiers can achieve a flow capacity of about $405 \mathrm{~m}^{3} \mathrm{~s}^{-1}$, which is $35 \%$ higher than that of the existing clarifiers.

The verification of 2-D clarifier model by using data illustrates that the $2 \mathrm{D}$ clarifier model is a very useful tool to optimize clarifier design and enhance clarifier performance by simulating tank internal hydraulics behavior and sludge blanket movement.

\section{Conclusions and recommendations}

Various possible modifications to the clarifier were presented, together with their predicted capacity and quality improvements. Results could probably be obtained with baffles located in a number of positions, for instance a horizontal baffle attached to the outer wall of the clarifier, below the clarified water launder. Such a baffle would be very much larger than the one proposed because of its radius, and consequently much more expensive to install.

The simulations suggested that an increase of $50 \%$ in throughput could be achieved with the installation of the mounted baffle, and this could be increased to $75 \%$ or more by combining it with an additional clarified water off-take. Even if these conclusions are optimistic, the low cost of fitting the baffle should make the baffle-only option worthwhile.

The additional clarified water off-take system would only be considered as a final option, as its engineering will be more involved and expensive

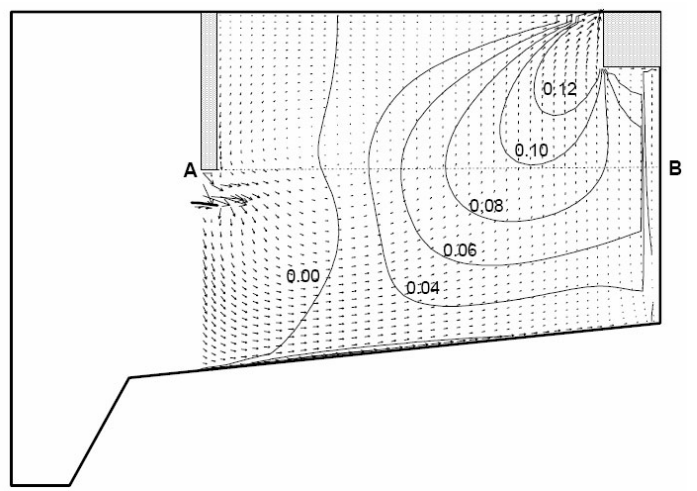

Fig. 6. Simulation of the clarifier modified with a baffle mounted below the shroud (contours of vertical velocity in $\mathrm{cm} \mathrm{s}^{-1}$ ).

Obr 6. Simulácia číriča upraveného pridaním usmerňovača umiestneného pod clonu (čiary vertikálnej rýchlosti $\mathrm{v} \mathrm{cm} \mathrm{s}^{-1}$ ). 


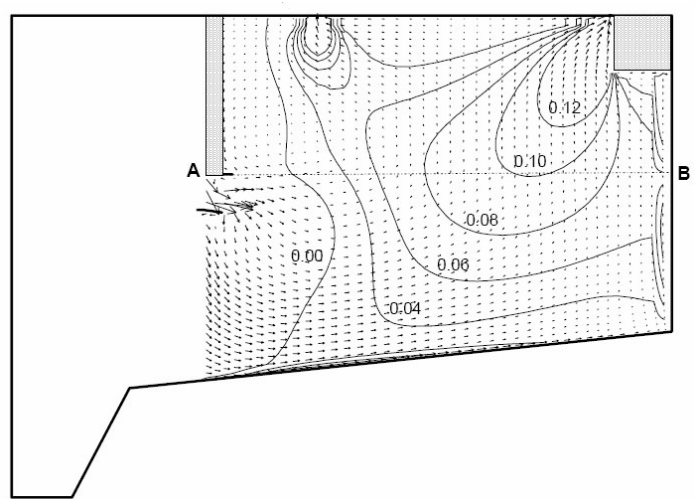

Fig. 7. Simulation of the clarifier modified with a baffle mounted on the shroud, and annular clarifier water withdrawal system (contours of vertical velocity).

Obr. 7. Simulácia číriča upraveného pridaním usmerňovača umiestneného na clone a systému odberu vody s prstencovým číričom (čiary vertikálnej rýchlosti).

than the installation of baffles, and in fact it is predicted to be largely ineffective without the baffles. However, there are apparently a considerable number of clarifiers of similar design around Bagh$\mathrm{dad} /$ Iraq, and it may be worthwhile to set up a clarifier with the complete system as a test case to develop a package which could be used to uprate units at works where greater capacity is required.

This project in general assessment determined that:

1. The renovation of Al-Wathba water treatment plant will meet the stated objective of improving the living conditions of citizens living in Baghdad by increasing the quality of potable water available to them, if design specifications are met.

2. The conclusion of that investigation had been that converting the clarifier to a central feed arrangement was the only way to obtain a significant improvement in its performance.

3. Evaluated clarifier design under the specified process conditions.

4. Develop reliable retrofit alternatives with the best cost-effectiveness.

Acknowledgement. The article is supported by the Scientific Grant Agency of the Ministry of Education - VEGA Project No. 1/0854/08 dealt with at the Department of Sanitary and Environmental Engineering, Faculty of Civil Engineering, Slovak University of Technology Bratislava.

List of symbols

$x$ - axial coordinate,

$r$ - radial coordinate, $\begin{array}{ll}\text { u } & \text { axial velocity }\left[\mathrm{m} \mathrm{s}^{-1}\right],\end{array}$

$P \quad$ - the average pressure $[\mathrm{Pa}]$,

$\mu \quad-$ dynamic viscosity [Pa s],

$\rho \quad-$ bulk density $\left[\mathrm{kg} \mathrm{m}^{-3}\right]$,

$\rho_{l}, \rho_{s} \quad-$ liquid and dry solids densities $\left[\mathrm{kg} \mathrm{m}^{-3}\right]$,

$t \quad-$ time [s],

$\mathrm{c}_{\mu} \quad$ - a model constant (0.09),

$k-$ the turbulent kinetic energy $\left[\mathrm{m}^{2} \mathrm{~s}^{-2}\right]$,

$\varepsilon \quad-$ the dissipation of turbulent energy $\left[\mathrm{m}^{2} \mathrm{~s}^{-3}\right]$,

$\sigma_{\mathrm{c}} \quad-$ the Schmidt number (0.7),

$v_{t} \quad-$ the turbulent viscosity $\left[\mathrm{m}^{2} \mathrm{~s}^{-1}\right]$,

$v_{\text {eff }}$ - effective viscosity $\left[\mathrm{m}^{2} \mathrm{~s}^{-1}\right]$,

$U_{s o} \quad$ - the reference settling velocity $\left[\mathrm{m} \mathrm{s}^{-1}\right]$,

$r_{h}, r_{p} \quad$ - induce the domination of the first and the second term for the falling and the rising part

$X_{0} \quad-$ the solid concentration [mg l${ }^{-1}$ ],

$\Phi \quad$ - solids mass fraction,

$v \quad-$ radial velocity $\left[\mathrm{m} \mathrm{s}^{-1}\right]$,

$v_{0} \quad-$ maximum settling velocity $\left[\mathrm{m} \mathrm{s}^{-1}\right]$,

A - the scraper displacement area $\left[\mathrm{m}^{2}\right]$,

CFD - Computational Fluid Dynamics.

\section{REFERENCES}

ADAMS E.W., RODI W., 1990: Modeling flow and mixing in sedimentation tanks. J. Hydr. Engng., 116, 7, pp. 895-913.

APHA, 1992: Standard methods for the examination of water and wastewater. Eds. Clesceri L.S, Greenberg A.E. and Eaton A.D., $2^{\text {nd }}$ Ed. APHA, Washington DC, USA.

BROUCKAERT C.J., BUCKLEY C.A., 1999: The use of computational fluid dynamics for improving the design and operation of water and wastewater treatment plants. Wat. Sci. Tech., 40, 4-5, pp. 81-89.

EKAMA G.A., BARNARD J., GUNTHERT F., KREBS P., MCCORQUODALE J.A., and PARKER D.S., WAHLBERG E.J., 1997: Secondary Settling Tanks: Theory, Modelling, design and operation. Published by the International Association on Water Quality, STR No. 6, 1997, Richmond, UK.

FLUENT INC., 2006: Fluent Manual. USA.

GHAWI A., HADI, KRIŠ J., 2007:” Design and Optimization of Sedimentation Tank in Slovakia with CFD Modeling". 10th International Symposiumon Water Management and Hydraulic Engineering 2007 with special emphasis on the impact of hydraulic engineering construction on the environment 4-9 September 2007. Šibenik, Croatia.

JAYANTI S., NARAYANAN S., 2004: Computational study of particle-eddy interaction in sedimentation tanks. J. Environmental Eng., 130, 1, pp. 37-49.

RODI W., 1984: Turbulence models and their application in hydraulics - a state of the art review. Int. Assoc. Hydraulic Research, The Netherlands.

RODI W., 1993: Turbulence models and their application in hydraulics. $3^{\text {rd }}$ Ed., Balkema, Rotterdam, The Netherlands.

KREBS P., STAMOU A.I., GARCÍA-HERAS J.L. and RODI W., 1996: Influence of inlet and outlet configuration on the flow in secondary clarifiers. Wat. Sci. Tech., 34, 5-6, pp. 1-9.

LAKEHAL D., KREBS P., KRIJGSMAN J. and RODI W., 1999: Computing shear flow and sludge blanket in secondary clarifiers. J. Hydr. Engng., 125, 3, pp. 253-262.

PATRY G.G., TAKÁCS I., 1992: Settling of flocculation suspensions in secondary clarifiers. Water Research, Vol. 26, No. 4, pp. 473-479. 
SIMANJUNTAK, BOERIU, ROELVINK, 2009: Consideration on the sedimentation process in a settling basin. J. Hydrol. Hydromech., 57, 1, pp. 16-25.

SZALAI L., KREBS P. and RODI W., 1994: Simulation of flow in circular clarifiers with and without swirl. J. Hydr. Engng., 120, 1, pp. 4-21.

TAKÁCS I., PATRY G.G. and NOLASCO D., 1991: A dynamic model of the clarification-thickening process. Wat. Res., 25, 10, pp. 1263-1271.

ZHOU S., McCORQUODALE J.A., 1992: Mathematical modelling of a circular clarifier. Can. J. Civ. Eng., 19, pp. $365-374$

Received 22 April 2009

Accepted 10 February 2010

\section{ZLEPŠENIE ČINNOSTI SEDIMENTAČNEJ NÁDRŽE AL-WATHBA POMOCOU CFD MODELU - POČÍTAČOVEJ SIMULÁCIE PRÚDENIA KVAPALÍN}

\author{
Jozef Kriš, Ghawi A. Hadi
}

Al-Wathba je fungujúca úpravňa pitnej vody v Bagdade. Jej účelom je čerpat' vodu z rieky Tigris, upravit' vodu podl'a pitných noriem a dopravit' ju do miestneho distribučného systému. Zariadenie bolo skonštruované v roku 1934 a rozšírené v rokoch 1964 a 1976. V dôsledku zanedbania úpravňa vyžaduje nákladnú rekonštrukciu.

Úpravňa vody Al-Wathba je viac ako 40 rokov stará a zanedbaná. Zle udržiavané zariadenie produkovalo približne $1000 \mathrm{~m}^{3}$ pitnej vody za hodinu. Kapacita úpravne sa rekonštrukciou zväčšila a teraz je schopná produkovat' $2400 \mathrm{~m}^{3}$ pitnej vody za deň.

Súčasná prevádzka zahŕňa čerpanie vody z rieky Tigris a úpravu vody prostredníctvom troch paralelných systémov úpravy. 1. systém bol postavený v roku 1934 a pozostáva $\mathrm{z}$ číriča, sedimentačnej nádrže, prípravy a prívodu síranu hlinitého do číriča, tlakovej filtrácie, chlorácie a čerpadiel, ktoré čerpajú vodu do distribučného systému. 2.systém úpravy bol skonštruovaný v roku 1964 a zahŕňa privádzač síranu hlinitého do číriacich nádrží s rýchlym miešaním, sedimentačnej nádrže, číriča, rýchlej gravitačnej otvorenej pieskovej filtrácie, chlorácie a čerpadiel, ktoré čerpajú vodu do distribučného systému. 3. systém postavený v roku 1976 je gravitačnou filtračnou sústavou, ktorá je podobná systému 2.

Pre modelovanie transportu pevných častíc v číriči je zásadná počítačová simulácia prúdenia kvapalín. Na výpočet pola prúdenia je potrebné riešit' rovnice pre hmotu (kontinuitu), axiálne a radiálne zachovanie hybnosti a objemovú hmotnost' (Ekama a kol., 1997).

Navrhnutý postup modeluje vodu a kal ako zmes $\mathrm{s}$ rovnakou rýchlost'ou pre všetky zložky zmesi. Ak vezmeme do úvahy špecifické procesy transportu pre kal, napr. usadzovanie, môžeme zostavit’ tzv. skalárne transportné rovnice.
Rýchlost' usadzovania rozptýlených pevných častíc nie je konštantná a závisí od teploty vody, vel'kosti vločiek, hustoty vločiek a ich koncentrácie. Rýchlost' usadzovania bola špecifikovaná ako funkcia koncentrácie (Takács, Patry, Nolasco (1991) a Patry, Takács (1992)). Táto formulácia umožňuje vyššie rýchlosti usadzovania pre vyššie koncentrácie a nižšie rýchlosti usadzovania pre nižšie koncentrácie.

Pred tým, ako štúdia dosiahla stupeň implementácie a hodnotenia, bola Al-Wathba schopná znížit potrebu vody na úpravni elimináciou niektorých vel'kých únikov $\mathrm{v}$ systéme a zmodernizovaním číriča. Hoci to bolo $\mathrm{z}$ pohl'adu projektu CFD sklamaním, poskytlo to názornú lekciu o potrebe aplikovat' manažment dopytu (potreby vody) pred zvážením technologických opatrení na zvýšenie produkčnej kapacity.

$\mathrm{V}$ tejto prípadovej štúdii bola vypracovaná séria modelov CFD na podporu návrhových prác pre úpravu číriča. Periférne usporiadanie prívodov pre tento čírič bolo dost' nezvyčajné a zlé rozmiestnenie prívodov vyústilo do nepriaznivého skratovania.

V júni 2005 uskutočnila Al-Wathba Water revíziu konštrukcie a následné odporúčania týkajúce sa navrhnutých vylepšení pre čírič. Pracovná skupina predložila takýto návrh vylepšenia:

Zmenit' existujúci periferálny vtokový systém na centrálny vtok, ktorý vyžadoval konštrukciu vtokového potrubia pod existujúcim dnom (obr. 2). Obr. 2 je prierezový nákres, predstavujúci charakteristiky číriča, ktoré sú dôležité pre model CFD.

Simulované koncentrácie pevných častíc by sa mali porovnávat's meranými profilmi. Validácia pozostávala $\mathrm{z}$ porovnávania simulácií $\mathrm{s}$ profilmi koncentrácií pevných častíc $\mathrm{v}$ ustálenom stave, ktoré boli merané v štyroch rôznych radiálnych vzdialenostiach, t.j. 2, 4, 6 a 7 metrov - všetky boli situované mimo prívodu. Profilovanie sa uskutočnilo pri poobedňajších prietokoch. Simulované profily boli zaznamenávané každých 20 minút $\mathrm{v}$ rozsahu profilov, medzi ktorými by sa mali nájst' merané koncentrácie pevných častíc pre úspešnú validáciu.

Ako vidiet' na obr. 4, v odtoku z úpravne vody AlWathba sú často zistené vysoké koncentrácie pevných častíc. V pret’aženom číriči je koncentrácia pevných častíc v odtoku vel'mi citlivá na akékol'vek nepatrné zmeny v prúdení.

$\mathrm{V}$ rámci prietokovej kapacity pre čírič v Al-Wathba boli pozorované rozsahy od 200 do $450 \mathrm{~m}^{3} \mathrm{~h}^{-1} \mathrm{v}$ dôsledku zmien parametrov procesu. Ćírič nie je schopný dosiahnut' predpokladaný návrhový prietok $405 \mathrm{~m}^{3} \mathrm{~h}^{-1}$, a to hlavne v dôsledku obmedzeného zahust'ovania v číriči.

Obr. 5 znázorňuje prierezový diagram modifikovaného číriča so simulovaným pol'om prúdenia pre prepadový prietok $242 \mathrm{~m}^{3} \mathrm{~h}^{-1}$, ktorý korešponduje s priemerným prúdením smerom nahor $0,045 \mathrm{~cm} \mathrm{~s}^{-1}$ cez prstencovú plochu medzi usmerňovačom a vonkajšou stenou. Šípky dávajú predstavu o spôsobe prúdenia $\mathrm{v}$ usadzovacej časti; ich dížky sú proporčné k rýchlostiam. Čiary znázorňujú distribúciu vertikálnej zložky rýchlosti. 
Kritická horizontálna rovina je braná od spodku usmerňovača $\mathrm{k}$ vonkajšej stene (znázornené ako $\mathrm{AB}$ na obr. 5) a možno vidiet', že maximálna rýchlost' smerom nahor v tejto časti je len niečo menej ako $0,12 \mathrm{~cm} \mathrm{~s}^{-1}$, čo je trojnásobok nominálnej návrhovej hodnoty. Takisto možno vidiet', že je to spôsobené tým, že výraznú čast' plochy smerom k stredu zaberajú vody prúdiace smerom nadol, čo znižuje účinnú oblast' časti usadzovania.

Na základe výsledkov sa zdá, že pokusy zvýšit' kapacitu číriča sú zamerané na zväčšenie oblasti, kde sa vyskytuje prúdenie smerom nahor cez minimalizovanie oblasti s výskytom prúdenia smerom nadol.

2D modelovanie technológie číriča bolo použité na vyhodnotenie alternatívy pre zavedenie novej technológie. Vylepšený hydraulický režim číriča ako aj jeho zlepšená činnost' sú zjavné v nasledujúcich aspektoch:

1. Bolo snahou dosiahnut' rovnomernejšiu distribúciu radiálneho prúdenia smerom von cez cylindrickú oblast' medzi dolným okrajom clony a dnom číriča hned' pod ním a tým znížit' cirkulačné prúdenie v usadzovacej časti (obr. 6). Vnútorný okraj usmerňovača mierne vyčnieva do dolného prúdenia vo vnútri clony a odkláňa ho do usadzovacej časti. Najlepší výsledok bol dosiahnutý s usmerňovačom smerujúcim mierne nadol, čo zabraňuje kalu dostat' sa okamžite do oblasti nad spodným okrajom clony. Nanešt'astie toto komplikuje skonštruovanie usmerňovača, ked’že robí z jeho povrchu skôr kónický úsek ako prstencový, ak je uhol jednoducho horizontálny. Ako vidiet', simulácia predpovedá, že tento usmerňovač môže mat' za následok zlepšenie kapacity približne o $25 \%$.

2. Ďalšiu kapacitu možno dosiahnut' použitím d'alšieho systému na odber upravenej vody tak, ako je znázornené na obr. 7. Muselo by to byt' prstencové potrubie plávajúce hned' pod hladinou so sériou otvorov pre vstup upravenej vody. Celá zostava by mala rotovat' $\mathrm{s}$ mostíkom $\mathrm{s}$ odberovou rúrou pripevnenou $\mathrm{k}$ mostíku, ktorá vypúšt'a vodu cez priepad do zberného žl’abu pre upravenú vodu. Toto možno dosiahnut' úpravou sifónu, ale je pravdepodobnejšie, že bude potrebné čerpadlo, ktoré taktiež možno pripevnit' $\mathrm{k}$ mostíku. Zdá sa, že inštalácia takejto úpravy by bola relatívne nákladná a priniesla by problémy s prevádzkou, ktoré by bolo t’ažké odôvodnit' na úpravni vody Al-Wathba. So všetkými inštalovanými možnost'ami simulácia predpokladá, že v porovnaní s pôvodným čírič bude mat' $175 \%$ kapacitu.

Vzt'ah medzi koncentráciou pevných častíc v odtoku a hydraulickým zat’ažením pre existujúci čírič a 3 d’alšie kombinácie modifikácií je zhrnutý v tab. 4.

Predpokladaná koncentrácia pevných častíc v tab. 4 naznačuje, že priemerná koncentrácia pevných častíc môže byt' výrazne znížená zlepšením hydraulickej účinnosti. Porovnanie modelových predpovedí s následne získanými údajmi z meraní naznačuje, že výrazné zlepšenie činnosti nádrže sa dosiahlo použitím malých modifikácií na základe $2 \mathrm{D}$ počítačového modelovania.

Za normálnych podmienok prevádzky, čo je po väčšinu roka, existujúci čírič má prietokovú kapacitu približne $290 \mathrm{~m}^{3} \mathrm{~h}^{-1}$. Optimalizované číriče môžu dosiahnut' prietokovú kapacitu $405 \mathrm{~m}^{3} \mathrm{~s}^{-1}$, čo je o $35 \%$ viac ako v súčasnej nádrži.

Verifikácia 2D modelu číriča s použitím údajov ukazuje, že 2D model nádrže je vel'mi užitočným nástrojom pre optimalizáciu návrhu číriča a zlepšuje jej činnost' tým, že simuluje vnútorný hydraulický režim pohybu kalového mraku.

V práci boli prezentované rôzne potenciálne modifikácie sedimentačnej nádrže spolu s predpokladanou kapacitou a zlepšením kvality. Výsledky môžu byt' dosiahnuté prostredníctvom usmerňovačov umiestnených na rôznych pozíciách, napr. horizontálny usmerňovač upevnený k vonkajšej stene nádrže pod číriacim zariadením. Takýto usmerňovač by bol vzhl'adom na jeho polomer ovel'a väčší ako ten navrhnutý a takisto aj inštalácia by bola nákladnejšia.

Na základe simulácií sa odporúča nárast priechodnosti o $50 \%$ pomocou inštalovania montovaného usmerňovača; nárast o $75 \%$ možno dosiahnut' kombináciou s dodatočným odtokom upravenej vody. Aj ked' sú tieto závery optimistické, nízke náklady na inštalovanie usmerňovača by znamenali, že usmerňovač je jediná možnost', ktorá sa vyplatí.

\section{Zoznam symbolov}

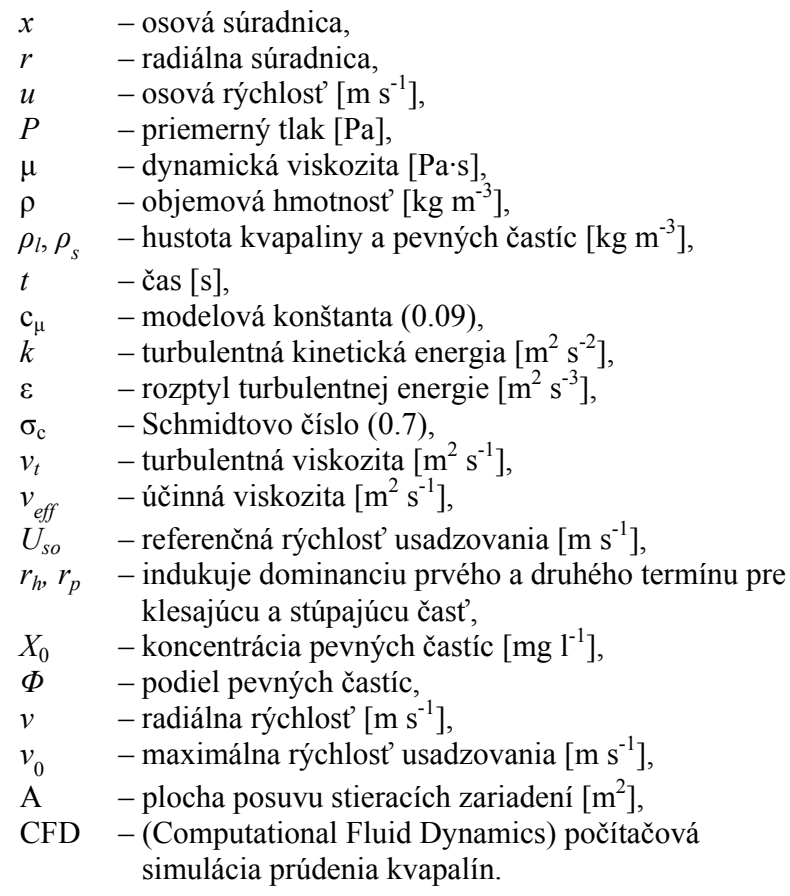

